\title{
Welfare Effects of Tax Policy in Open Economies: Stabilization and Cooperation*
}

\author{
Jinill Kim, Federal Reserve Board ${ }^{\dagger}$ \\ Sunghyun Henry Kim, Tufts University
}

September, 2003

\begin{abstract}
This paper studies an international tax policy design problem by employing a two-country dynamic general equilibrium model with incomplete asset markets. We investigate the possibility of welfareimproving active tax policies, in particular capital and labor income tax, under the non-cooperative Nash equilibrium and the cooperative equilibrium. Unlike the conventional wisdom regarding stabilization policies, optimal tax policies in our economy are procyclical. Relative to the non-cooperative setting, international tax policy cooperation requires more active tax policies (about two times) and generates large extra welfare gains (by about a third).
\end{abstract}

- JEL Classification: F4, E6;

- Key Words: income tax, welfare, stabilization, cooperation.

\footnotetext{
${ }^{*}$ We appreciate comments from Robert Kollmann, Juergen von Hagen, and seminar participants at Econometric Society Winter Meeting, Korea Economic Association International Conference, Society of Computational Economics Conference, Boston College, Clark University, the University of Bonn, the University of Montreal, and the University of Virginia, International Monetary Fund, and the Federal Reserve Board. The views in this paper are solely the responsibility of the authors and should not be interpreted as reflecting the view of the Board of Governors of the Federal Reserve System or any other person associated with the Federal Reserve System.

${ }^{\dagger}$ Mail Stop 70, Division of Monetary Affairs, Federal Reserve Board, Washington, DC 20551. Tel: 202-452-2981, Fax: 202-452-2301, E-mail: Jinill.Kim@frb.gov.

${ }^{\ddagger}$ Department of Economics, Tufts University, Medford, MA 02155. Tel: 617-627-3662, Fax: 617-627-3917, E-mail: sunghyun.kim@tufts.edu.
} 


\section{Introduction}

Many economists have argued that fiscal policy is not effective for stabilization purposes. However, fiscal policy can be effectively used for stabilization under some circumstances. An example is monetary union such as the European Union where stabilizing monetary policy is not available for regional shocks. ${ }^{1}$ In order to properly use active fiscal policy rules under these circumstances, it is important to obtain accurate welfare implications of fiscal policies.

This paper studies tax policy design problem within an optimizing twocountry model. In our model, a stabilization problem exists because of distortionary taxes and incomplete financial markets where sovereign bonds are the only internationally-traded asset. We develop a two-country singlegood dynamic stochastic general-equilibrium model to analyze the welfare effects of capital and labor income tax policy on the welfare level of each individual country as well as of the world. Each country faces productivity shocks and governments can affect business cycles by adjusting tax rates according to the realization of productivity shocks. Governments maintain balanced budget in each period by using lump-sum transfers.

After setting up the model, we analyze welfare gains of domestic tax policies on both domestic and foreign countries. We calculate the optimal level of tax rate adjustment to productivity shocks and the amount of maximum welfare gains. ${ }^{2}$ We also derive the non-cooperative Nash equilibrium. Finally, we investigate the possible gains of tax policy coordination by deriving cooperative equilibrium. If non-cooperative and cooperative equilibria are different, then there is room for welfare improvement via tax policy coordination. These results provide realistic implications about potential welfare effects of policy coordination across countries.

Three main contributions of this paper are as follows. First, we adopt an open-economy framework. The literature on welfare analysis of tax policy has focused on closed-economy. ${ }^{3}$ However, these results can dramatically

\footnotetext{
${ }^{1}$ Another case when monetary policy is ineffective is a deflationary economy with zero or negative real interest rate such as Japan in the late 1990s. See Feldstein (2002) for the discussion on the positive role of discretionary fiscal policy in this case.

${ }^{2}$ Our search for 'optimal' tax policy is by assuming a certain parametric family of tax policy rules and optimizing over the parameters of the rule. This exercise is similar to Mendoza and Tesar (1998) in that we consider welfare consequences of ad-hoc changes in taxes. Note that this is different from defining optimal tax policy as the best possible tax rate responses to disturbances, as in Chari et al. (1994).

${ }^{3}$ Papers with the closed economy setup include Greenwood and Huffman (1991), McGrattan (1994), and Chari et al. (1994). In many cases, tax policies aiming for the
} 
change under open economy because tax policies can have significant effects on other countries through various channels such as the world interest rate and capital flows. ${ }^{4}$ Second, we analyze tax policies in a stochastic setup, which has been used extensively for the analysis of monetary policy (e.g. Obstfeld and Rogoff 2002, and Canzoneri, Cumby and Diba 2002). Most papers in the literature have analyzed tax policies in a deterministic setup and focused on the effects of permanent changes in tax policies or tax policy reform. ${ }^{5}$ However, certain economic phenomena should be analyzed under the stochastic framework. For example, recent discussion in the European Union about the role of fiscal policies as absorbers of asymmetric shocks is an example due to the stochastic nature of such shocks. Third, in order to capture the nonlinear dynamics of the model which matters for welfare analysis, we solve the model using a second-order accurate solution method. It is crucial to adopt a second-order method in calculating the level of welfare because the conventional method of linearization, such as the one used in King, Plosser and Rebelo (1988), produces inaccurate welfare calculation as documented in Kim and Kim (2003).

Our main findings are as follows. The optimal tax response to a $1 \%$ increase in home productivity, assuming no tax policies in the foreign country, is to decrease capital income tax rate by $2.2 \%$ or to decrease labor income tax rate by $0.2 \%$. Optimality of procyclical policy is analogous to the procyclical nature of optimal monetary policy when shocks are from the supply side, as shown in Ireland (1996), Obstfeld and Rogoff (2002), and Kim and Henderson (2002). Two best response functions of optimal tax policy by home and foreign country show that the non-cooperative Nash equilibrium is achieved when the two income tax rates decrease by $2.8 \%$ and $0.2 \%$, respectively. These optimal tax policies, however, maximize only the level of domestic welfare. We also calculate the cooperative equilibrium that maximizes the level of world welfare. In the cooperative equilibrium, the optimal tax rates respond more to productivity shocks and there are significant extra welfare gains relative to the Nash equilibrium.

Section 2 describes a two-country model of a production economy with

stabilization of the economy produce allocation distortions that outweigh the stabilization gains and therefore reduce welfare. Tax policies can be welfare-improving if the economy is already subject to other distortions such as imperfect competition or externalities, e.g. Easley et al. (1993) and Hairault et al. (2001).

${ }^{4}$ Baxter (1997) and Kollmann (1998) examined the effects of taxes as well as government spending to explain the twin deficits and the U.S. trade balance, respectively.

${ }^{5}$ Papers with deterministic open-economy models include Frenkel and Razin (1992), Easterly and Rebelo (1993), Razin and Sadka (1994), Bovenberg (1994), Karayalcin (1995), and Mendoza and Tesar (1998, 2001). 
capital and labor. We also explain the second-order accurate solution method. In section 3, we calculate optimal tax policies and analyze impulse responses to productivity shocks with and without tax policies to help interpret the welfare results. Section 4 provides the results of sensitivity analysis. We first calculate optimal tax policies when governments can use both income tax policies at the same time. We also analyze welfare implications when governments change consumption tax rate to balance their budget instead of using lump-sum transfers. Finally, section 5 offers the conclusion of the paper.

\section{The Model}

The economy consists of two countries which have the identical preference and production technology. There is a single nondurable tradable good serving as the numeraire. Each country consists of a representative household, a representative firm, and a government. Households decide the level of consumption, leisure, investment, and bond holdings subject to budget constraints. Bond holdings and investment are subject to adjustment costs. We assume that capital is perfectly mobile across countries and the international financial market is incomplete in the sense that agents can trade only state-non-contingent bonds.

The government is described as a sequence of government spending and tax rates on consumption, capital income and labor income. The entire amount of tax revenue, net of fixed government spending, is distributed to households as lump-sum transfers in each period. The transfers can be negative and in this case they operate as lump-sum taxes. The use of lump-sum transfers allows us to avoid potential additional distortions from adjusting other tax rates to balance the budget in each period. This assumption is relaxed in section 4 . The only source of disturbances in the economy is productivity shocks which can be correlated across countries. Foreign variables are denoted by asterisks and their behavior is symmetric to the home country when not specified.

\subsection{Households and Firms}

Households enter the market owning one unit of labor at time $t$ with predetermined capital and bond holding. The household receives its wage and rental income from firms, and its interest income out of risk-free bonds.

Household in each country maximizes the expected lifetime utility given 
by

$$
\mathrm{E}_{0} \sum_{t=0}^{\infty} \beta^{t} U_{t}, \text { where } U_{t}=\frac{\left[C_{t}^{\theta}\left(1-L_{t}\right)^{1-\theta}\right]^{1-\sigma}}{1-\sigma},
$$

where $C_{t}$ is the level of consumption, and $1-L_{t}$ the amount of leisure. Households in both countries have the same discount factor $\beta$.

The budget constraint of household is given by:

$$
\begin{aligned}
& \left(1+\tau_{c t}\right) C_{t}+I_{t}+B_{t}+\frac{\zeta}{2}\left(B_{t}\right)^{2} \\
= & \left(1-\tau_{l t}\right) w_{t} L_{t}+\left[\left(1-\tau_{k t}\right) r_{t}+\tau_{k t} \delta\right] K_{t}+R_{t-1} B_{t-1}+T_{t},
\end{aligned}
$$

where $B_{t}$ denotes the quantity of international bonds purchased in period $t$ maturing in $t+1, R_{t}$ is the gross interest rate on bonds, $r_{t}$ is the rental rate, $w_{t}$ is the wage rate, and $\tau$ represents tax rates $\left(\tau_{c}=\right.$ consumption tax rate, $\tau_{k}=$ capital income tax rate and $\tau_{l}=$ labor income tax rate). Note that there is a depreciation allowance, $\tau_{k t} \delta K_{t}$, and bond holdings are subject to quadratic holding costs, $\frac{\zeta}{2}\left(B_{t}\right)^{2} \cdot{ }^{6} T_{t}$ is the lump-sum transfer (tax) to the household which amounts to the budget surplus (deficit).

As in Kim (2003), households accumulate capital according to the following equation:

$$
K_{t+1}=\left[\delta\left(I_{t} / \delta\right)^{1-\phi}+(1-\delta) K_{t}^{1-\phi}\right]^{\frac{1}{1-\phi}}
$$

A zero $\phi$ implies no adjustment costs. A positive $\phi$ implies the presence of adjustment costs and $\phi=1$ corresponds to a loglinear capital accumulation equation. ${ }^{7}$

For firms, the production function follows a Cobb-Douglas form with labor and capital,

$$
Y_{t}=A_{t} L_{t}^{\alpha} K_{t}^{1-\alpha}
$$

While labor cannot move across countries, investment in the domestic country can be financed by foreign capital. A No-Ponzi-Game condition is imposed on the household's borrowing.

\footnotetext{
${ }^{6}$ The presence of bond holding adjustment costs allows us to avoid the nonstationarity problem associated with incomplete asset markets. However, we set the parameter $\zeta$ extremely small so that there are only negligible effects of bond holding costs on model dynamics or welfare. See Kim and Kose (2003) and Schmitt-Grohé and Uribe (2003) for a detailed discussion on this issue.

${ }^{7}$ See Kim (2003) for comparison of this with other specifications of investment adjustment costs.
} 


\subsection{Shocks and the Government}

Productivity variable $A_{t}$ and $A_{t}^{*}$, representing stochastic components of the production functions of the two countries, follow a symmetric vector Markov process:

$$
\left[\begin{array}{l}
\log \left(A_{t}\right) \\
\log \left(A_{t}^{*}\right)
\end{array}\right]=\left[\begin{array}{ll}
\rho_{A} & \nu_{A} \\
\nu_{A} & \rho_{A}
\end{array}\right]\left[\begin{array}{l}
\log \left(A_{t-1}\right) \\
\log \left(A_{t-1}^{*}\right)
\end{array}\right]+\left[\begin{array}{l}
\varepsilon_{A_{t}} \\
\varepsilon_{A_{t}}^{*}
\end{array}\right] .
$$

where $E\left(\varepsilon_{A_{t}}\right)=E\left(\varepsilon_{A_{t}}^{*}\right)=0, E\left(\varepsilon_{A_{t}}^{2}\right)=\sigma_{\varepsilon_{A}}^{2}, E\left(\left(\varepsilon_{A_{t}}^{*}\right)^{2}\right)=\sigma_{\varepsilon_{A}^{*}}^{2}$, and $\rho\left(\varepsilon_{A_{t}}, \varepsilon_{A_{t}}^{*}\right)=$ $\psi_{A}$ for all $t$. $\rho_{A}$ is the persistence of productivity shocks and $\nu_{A}$ represents the spillover effects. A non-zero $\psi_{A}$ means that the innovations are contemporaneously correlated across countries.

In the benchmark case of exogenous tax policy, the tax rates are assumed to follow an AR(1) stationary process, as in McGrattan (1994) and Baxter (1997):

$$
\begin{aligned}
\tau_{c t} & =\rho_{c} \tau_{c, t-1}+\left(1-\rho_{c}\right) \bar{\tau}_{c}+\varepsilon_{\tau_{c} t}, \\
\tau_{k t} & =\rho_{k} \tau_{k, t-1}+\left(1-\rho_{k}\right) \bar{\tau}_{k}+\varepsilon_{\tau_{k} t}, \\
\tau_{l t} & =\rho_{l} \tau_{l, t-1}+\left(1-\rho_{l}\right) \bar{\tau}_{l}+\varepsilon_{\tau_{l} t},
\end{aligned}
$$

where $\bar{\tau}$ is the steady state tax rate and $\varepsilon_{\tau t}$ is an exogenous error term in tax rate process. Later, we will analyze endogenous tax policy by replacing $\varepsilon_{\tau t}$ with tax responses to productivity shocks.

Government income also includes bond holding adjustment costs, and government spending $G_{t}$ is assumed to be fixed and unproductive. The government does not issue any debt and balances its budget in each period by rebating all the tax revenue to households. That is, the level of the government transfer satisfies

$$
\tau_{c t} C_{t}+\tau_{l t} w_{t} L_{t}+\tau_{k t}\left(r_{t}-\delta\right) K_{t}+\frac{\zeta}{2}\left(B_{t}\right)^{2}=G_{t}+T_{t}
$$

Domestic equilibrium is restricted by the optimizing behavior of the household and the firm, and the government policy regarding tax and transfer. The country's resource constraint is

$$
Y_{t}+R_{t-1} B_{t-1}=C_{t}+I_{t}+G_{t}+B_{t} .
$$

For the world equilibrium, the model requires bond market-clearing condition that bonds should be in zero net supply:

$$
B_{t}+B_{t}^{*}=0 .
$$

The equations describing the equilibrium are listed in the Appendix. 


\subsection{Calibration}

As for calibration, we use the conventional parameter values for annual data. We use the annual data because tax rates do not vary much on a quarterly basis. Capital depreciation rate, $\delta$, is 0.1 per year. Labor share, $\alpha$, is 0.6 and the consumption share parameter, $\theta$, is set to match the steady state share of time devoted to market activities, 0.4. The representative agent's discount factor, $\beta$, is 0.95 so that the steady state annual real interest rate is equal to $5 \%$. We set the utility curvature parameter, $\sigma$, which determines the household's coefficient of relative risk aversion at 2 . The elasticity of bond holding costs, $\zeta$, is set at $10^{-5}$ to allow only minimal effects from holding costs. Government spending is fixed at the level that allows balanced budget under the steady state. Finally, we need to decide the parameter value for $\phi$ in capital adjustment costs. We set it at 0.2 to match the volatility of investment in the data. Most previous studies reported that productivity measures are highly persistent. We follow Backus et al. (1992) and Baxter and Crucini (1995) and assume that $\rho_{A}=0.906, v_{A}=0.088, \sigma_{\varepsilon_{A}}=0.852 \%$, and $\rho\left(\varepsilon_{A_{t}}, \varepsilon_{A_{t}}^{*}\right)=\psi_{A}=0.254$.

Measuring aggregate tax rates is a complex and difficult task and there is little consensus on effective tax rate measures. In this paper, we use the aggregate effective tax rates calculated by Mendoza et al. (1994). ${ }^{8}$ They calculate effective tax rates for G-7 countries by dividing actual tax payments by corresponding national accounts. These effective tax rates reflect government policies on tax credits, deductions, and exemptions as well as information on statutory tax rates. These tax rates also reflect the private sector's behavior on tax payment over time. Moreover, they are consistent with the concept of aggregate tax rates at the national level and with the assumption of representative agents. These estimates, however, can be sensitive to cyclical factors and shocks to tax revenues and bases.

Table 1 reports the properties of tax rates of G-7 countries. Average tax rates are $12 \%, 31 \%$ and $36 \%$ for consumption, labor income and capital income tax, respectively. We use these values as steady state tax rates. ${ }^{9}$

\footnotetext{
${ }^{8}$ Their method is in the same line with Lucas (1990) and Razin and Sadka (1994). A number of papers have used this method to construct data on tax rates. See, for example, Mendoza and Tesar (1998). Another widely-used alternative for tax rate data is aggregate marginal tax rates. See Mendoza et al. (1994) for a detailed explanation and comparison of different computation methods.

${ }^{9}$ Instead of calibrating the steady-state tax rates, one can calculate optimal tax rates by a Ramsey approach of solving an optimal commitment solution. However, the rules approach combined with calibrating the steady state is more appropriate to deal with the stabilization and cooperation issues of this paper.
} 
Table 1 also reports correlation among different tax rates within a country. The correlation between the two factor income taxes (labor and capital) is significantly positive and high in many cases (average of 0.53 ). This indicates that governments tend to move both types of income tax in the same direction. The correlation between consumption and factor income taxes is low and negative in some cases.

We estimate the tax rate process assuming an $\mathrm{AR}(1)$ structure of tax rates. Table 2 shows that all tax rates are highly persistent. The average $\mathrm{AR}(1)$ coefficients for G-7 countries are $0.84,0.91$ and 0.81 for consumption, labor income and capital incomes taxes, respectively. We calibrate the persistence parameter at these values. The standard deviation of the residual terms of tax rates are $0.7 \%, 1 \%$ and $2.7 \%$ for consumption, labor income and capital incomes taxes, respectively. Capital income tax shocks are much more volatile than the other two tax shocks, especially in US and UK (4.5\% and $6 \%$, respectively). Compared to the productivity shocks, tax shocks are as much as or more volatile on average (estimated standard deviation of productivity shocks are less than $1 \%$ on average). Even though our focus is on the normative side, these numbers indicate that the tax policies that are more than unit elastic to the productivity shocks are within the range of empirical observation.

\subsection{Solution Method}

We adopt a second-order accurate solution method to correctly calculate the level of welfare. The accuracy of the conventional linearization method, as in King, Plosser and Rebelo (1988), is widely known to be satisfactory in computing second moments such as variances and correlation coefficients. However, the linearization method can generate inaccurate results in terms of welfare calculations, especially in open-economy models. ${ }^{10} \mathrm{Kim}$ and Kim (2003) developed a "bias correction method" to compute the level of welfare, which generates as accurate a solution as the full second-order approximation method in terms of welfare calculation. ${ }^{11}$ The basic idea of the bias correction method is to summarize the second-order terms of the solution

\footnotetext{
${ }^{10} \mathrm{Kim}$ and $\mathrm{Kim}$ (2003) showed that the conventional linearization is so inaccurate as to generate a paradoxical result that the level of welfare under autarky is higher than that under the complete markets using a two-country model.

${ }^{11}$ This is similar to the concept of correcting a bias of an estimator in econometrics. Appendix explains the pitfalls of linearization in welfare analysis and proves the validity of the bias correction method in computing the level of welfare. Kim et al. (2003) discusses the second order solution in a broader context.
} 
as their expectations and use such expected values to correct the first-order solution.

\section{Welfare Implications}

This section analyzes welfare implications of active tax policies, in particular capital and labor income tax policies. The government implements active tax policies by changing the tax rates according to the observation of the current-period productivity shock. ${ }^{12}$ That is, tax policies are represented by the parameter $\eta$ 's in

$$
\begin{aligned}
\tau_{k t} & =\rho_{k} \tau_{k, t-1}+\left(1-\rho_{k}\right) \bar{\tau}_{k}+\eta_{k} \varepsilon_{A t}, \\
\tau_{l t} & =\rho_{l} \tau_{l, t-1}+\left(1-\rho_{l}\right) \bar{\tau}_{l}+\eta_{l} \varepsilon_{A t},
\end{aligned}
$$

where the sign of $\eta$ 's indicates whether the tax policies are countercyclical (if positive) or procyclical (if negative), and the absolute value of $\eta$ represents the sensitivity of tax policy (i.e. how much tax rate should be changed to a unit change in productivity). We remove exogenous error terms $\varepsilon_{\tau t}$ from the tax rate process by assuming that governments can adjust tax rates without any uncertainties.

We measure welfare gains by calculating the change in welfare when the government implements endogenous tax policies to the benchmark economy. In the benchmark economy, both countries face stochastic productivity shocks but tax rates are fixed at the steady state level $\left(\eta_{k}=\eta_{l}=0\right)$. Welfare is measured in terms of consumption units, a common measure in business cycle literature as in Lucas (1987). The certainty equivalent consumption is based on the conditional expectation of expected lifetime utility. ${ }^{13}$

\subsection{Capital Income Tax Policy}

We first consider a case when foreign tax policy is exogenous. That is, we derive the optimal endogenous tax policies of the domestic country when the foreign country's tax rates are fixed at the steady state. Then, by varying the reaction of the foreign country's endogenous tax policy, we draw the best

\footnotetext{
${ }^{12}$ Another possible form of tax policy is to change tax rate in response to the changes in directly observable data such as output. However, both types of policies give similar results.

${ }^{13}$ It is important to use conditional mean, instead of unconditional mean, in order to correctly capture the dynamic transitional effects of policy changes. See Kim et al. (2003) for more on this.
} 
response curve of the domestic country and find the non-cooperative Nash equilibrium. Finally, we calculate the cooperative equilibrium and analyze gains from cooperation.

\subsubsection{Exogenous foreign tax policy}

Figure 1 shows the welfare gains of capital income tax policy when foreign tax policy is exogenous (i.e., $\eta_{k}^{*}=0$ ). In this case, procyclical tax policies (negative $\eta_{k}$ ) improve domestic welfare. That is, facing a positive productivity shock, a tax cut improves domestic welfare. Lowering tax rate with a positive productivity shock generates efficiency gains by stimulating agents to produce more in a more productive country and these efficiency gains exceed potential allocation distortions. ${ }^{14}$ The domestic welfare is maximized when $\eta_{k}=-2.2$, a decrease in capital income tax rate by $2.2 \%$ with a $1 \%$ increase in productivity shock. This policy is within the range of empirical observations in table 2 where the standard deviation of capital income tax innovations is $2.7 \%$. The maximum welfare gains are $0.003 \%$ of permanent consumption, as in Table 3 . We observe positive spillover effects of procyclical capital income tax policy in that the foreign welfare gains are positive at $0.0014 \%$.

To understand the mechanism through which welfare gains materialize, we look at how economy behaves when hit by a productivity shock under the active tax policy. Figure 2 compares the impulse responses to a positive productivity shock in a model with exogenous and endogenous capital income tax policy $\left(\eta_{k}\right.$ is set at 0 and -2.2 , respectively). The most significant effects are on investment. With procyclical capital income tax policy, investment rises almost twice more than under the exogenous tax policy for the first several years. In the economy with incomplete asset markets, the residents facing a higher productivity do not invest as much as they should were they in the world with complete asset markets. It is well known that output, investment and employment respond more to productivity shocks in the complete markets economy, compared to the incomplete markets economy. ${ }^{15}$ Therefore, the procyclical tax policy shifts the response of the incomplete markets economy towards the complete markets equilibrium, resulting in a higher level of welfare.

\footnotetext{
${ }^{14}$ It is interesting that, in a different framework, Yakadina (2002) also finds similar behavior of optimal capital income tax rates in response to technology shocks.

${ }^{15}$ See Baxter and Crucini (1995), Heathcote and Perri (2002), and Kim et al. (forthcoming) for details.
} 


\subsubsection{Non-cooperative and cooperative equilibrium}

Figure 3 shows the best response functions of the two countries. We have seen that optimal $\eta_{k}$ is -2.2 when $\eta_{k}^{*}=0$. However, as $\eta_{k}^{*}$ moves from 0 to -3 , the optimal policy $\eta_{k}$ changes from -2.2 to -2.8 . The Nash equilibrium is achieved when $\eta_{k}=\eta_{k}^{*}=-2.8$ and the welfare gains are $0.0065 \%$ which is around twice the domestic welfare gains when foreign country does not implement any tax policy. This is due to positive spillover effects.

This non-cooperative Nash equilibrium, however, does not maximize the world welfare. We define the cooperative equilibrium as the outcome when both countries use their tax policy to maximize the average of domestic and foreign welfare. ${ }^{16}$ For capital income tax, the cooperative equilibrium is achieved when $\eta_{k}=\eta_{k}^{*}=-5.6$, suggesting that the capital income tax rates should respond twice as much as the response under the Nash equilibrium for the maximization of world welfare. The welfare gain at the cooperative equilibrium is $0.0087 \%$. We measure the welfare gains from cooperation by the ratio of the gains from the Nash solution to the cooperative solution to the gain from a 'no response' solution to the Nash solution. This is in line with the way gains from coordination is measured in the open-economy literature on monetary policy (e.g. Obstfeld and Rogoff 2002, and Canzoneri, Cumby and Diba 2002). In the case of capital income tax, this measure is $(.0087-.0065) / .0065=.34$. That is, policy cooperation brings about $34 \%$ extra welfare gains relative to the Nash equilibrium.

\subsection{Labor Income Tax Policy}

In this part, we repeat the same exercise for labor income tax policy. Figure 4 plots the welfare gains of the two countries when the domestic government changes $\eta_{l}$ holding $\eta_{l}^{*}$ constant at zero. The maximum welfare gains are quite small at $0.0008 \%$ of permanent consumption, and it is achieved when $\eta_{l}=-0.2$, interpreted as a decrease in labor income tax rate by $0.2 \%$ with a $1 \%$ positive productivity shock. As was the case with capital income tax, the procyclical labor income tax policy (negative $\eta_{l}$ ) produces positive spillover effects and increases the level of foreign welfare. ${ }^{17}$

\footnotetext{
${ }^{16}$ In our cooperative solution, each country's tax rates respond to its own productivity shocks. It may bring more welfare gains if tax rates respond to foreign country's productivity shocks as well.

${ }^{17}$ In a Ramsey problem setting, Gorostiaga (2003) finds that the optimal tax policy features a procyclical nature in response to technology shocks. The optimal labor tax rates fluctuates very little, which is consistent with our findings.
} 
Figure 5 shows impulse responses to a $1 \%$ increase in productivity under exogenous tax policy $\left(\eta_{l}=0\right)$ and optimal labor income tax policy $\left(\eta_{l}=\right.$ -0.2 ). Under this procyclical labor income tax policy, domestic residents increase their working hours more in response to a positive productivity shock, resulting in higher output and consumption. As was the case with capital income tax, the incomplete asset markets imply that the residents facing a higher productivity do not work as much as they should were they in the world with complete asset markets. Therefore, the procyclical tax policy moves the outcome of the incomplete markets economy towards the complete markets equilibrium.

We can derive the Nash equilibrium by the best response functions drawn in Figure 6. The optimal tax policy stays unchanged when foreign tax policy moves from the 'no response' case, and the two reaction functions meet at $\eta_{l}=\eta_{l}^{*}=-0.2$. Because of the positive spillover, the welfare increases by $0.0015 \%$ in the Nash equilibrium. The cooperative equilibrium is achieved when the two countries implement more active policy at $\eta_{l}=\eta_{l}^{*}=-0.4$, and the size of welfare gain is $0.0020 \%$. Based on the same measure in the case of capital income tax, cooperation of the labor income tax policies yields $33 \%$ extra welfare gains relative to the Nash equilibrium outcome.

Compared to the case of capital income tax, the optimal response of labor income tax and the level of maximum welfare gains are quite small. This is because there is no restriction in cross-border capital movement and therefore agents can fully take advantage of cross-country productivity differences by allocating capital freely across countries. On the other hand, labor income tax policy has limited effects on production capacity because labor cannot move across countries in this model.

\section{Sensitivity Analysis}

To check the robustness of our results, we implement two types of sensitivity analysis.

\subsection{With Both Income Tax Policies}

Table 4 reports the optimal tax responses and the level of welfare gains when governments can use both capital and labor income tax policies at the same time. Compared to the results in Table 3 when the governments use only one type of income tax policy, the optimal tax responses become more procyclical with higher level of maximum welfare gains. In particular, with exogenous foreign tax policy, the optimal income tax responses are 
$\eta_{k}=-2.8$ and $\eta_{l}=-0.4$ (previously -2.2 and -0.2 , respectively). In the Nash equilibrium, optimal responses are $\eta_{k}=-3.3$ and $\eta_{l}=-0.4$ (previously -2.8 and -0.2 , respectively).

Welfare gains also increase. Under the Nash equilibrium, welfare gains are $0.0125 \%$ which is higher than the combined gains with independent policies, $0.0065 \%$ and $0.0015 \%$ with capital and labor income tax policies, respectively. This is due to positive cross-tax effects. That is, procyclical capital income tax policy has positive effects on labor supply and procyclical labor income tax policy has positive effects on investment. Therefore, a combination of two procyclical tax policies magnifies the positive responses of factor inputs under a positive productivity shocks and hence increases welfare gains. In the cooperative equilibrium, the optimal policies become extremely procyclical with $\eta_{k}=-16.0$ and $\eta_{l}=-2.3$. This is because procyclical tax policy has positive cross-tax spillover effects on foreign countries as well as within the domestic country. However, these responses are too volatile to be rationalized by the data.

\subsection{With Varying Consumption Tax}

We now change the assumption that governments balance their budget using lump sum transfers (taxes). The use of lump-sum transfers is sometimes criticized for being unrealistic despite its popularity (e.g. Greenwood and Huffman, 1991). In our second sensitivity analysis, we assume that lump sum transfers are fixed at their steady state level (of zero) and the governments change consumption tax rates to balance their budget. ${ }^{18}$ This modification will incur additional distortions and therefore different dynamic responses. Figure 7 compares impulse responses to a positive productivity shock under these two schemes in the benchmark case with no active tax policy. With fiscal transfers, a positive productivity shock increases lump sum transfers as the government returns extra tax revenues back to households. On the other hand, with varying consumption tax rate, the government should lower consumption tax rate to maintain balanced budget. A decrease in consumption tax rate in turn changes the impulse responses of other variables in both countries. In fact, all the variables respond more positively to a positive productivity shock compared to the case with varying lump sum transfers.

We calculate the level of welfare under the two balanced budget schemes in the benchmark case. Welfare level from the model with varying consumption tax rate is higher than that with varying fiscal transfers, by $0.06 \%$

\footnotetext{
${ }^{18}$ Mendoza and Tesar $(1998,2001)$ used the model where revenue loss due to income tax cuts is replaced by increasing consumption tax rate.
} 
of lifetime consumption. This sounds counterintuitive because adding additional distortion (consumption tax) in the economy usually lowers welfare. However, under incomplete financial markets, subsequent movements in consumption tax rate make the economy move more closely to the complete markets economy, compared to the case with varying lump sum transfers. That is, a decrease in consumption tax rate following a positive productivity shock allows domestic households to produce and consume more to the level under the complete markets economy.

Next, we analyze the welfare effects of active tax policy under the new balanced budget scheme. Table 4 reports the welfare gains assuming exogenous foreign tax policy. For capital income tax, optimal tax policy becomes less procyclical at $\eta_{k}=-1.7$. For labor income tax, the optimal tax policy becomes countercyclical with optimal $\eta_{l}=0.6$. In both cases, the amount of maximum welfare gains $(0.0066 \%$ and $0.0029 \%$, respectively) are larger than those with varying lump sum transfers $(0.003 \%$ and $0.0008 \%$, respectively). Subsequent changes in consumption tax rate following active income tax policy help domestic country to attain a higher level of welfare than before. The previous conclusion that the optimal income tax policy is procyclical still holds for the case of capital income tax but not for the labor income tax. Therefore, we can conclude that capital income tax policy is a better tool than the labor income tax policy in the sense that it generates more consistent and predictable responses of the economy.

\section{Conclusion}

We can summarize the welfare implications of active tax policies as follows. First, the optimal tax responses are procyclical. The conventional idea in the literature is that optimal tax policy is countercyclical rather than procyclical. This is due to the assumption of our model that the economy is subject to only productivity (supply) shocks to which the incomplete markets economy does not respond as much as it should. This finding is consistent with the closed-economy results in Gorostiaga (2003) and Yakadina (2002). Second, the procyclical tax policy generates positive spillovers to the foreign country. Third, the capital income tax policy is a better tool than the labor income tax policy because capital income tax policy incurs higher welfare gains in the open economy. Finally, additional welfare gains from tax policy cooperation is about $33 \%$ relative to the welfare gains of the Nash equilibrium.

In general, welfare gains from active tax policies are very small compared 
to welfare gains of tax policy reform that changes tax rates permanently, as considered in Mendoza and Tesar $(1998,2001)$. This is because the tax policies considered in this paper are fine-tuning in that tax rates can only respond to business cycles in the economy. However, it is less difficult to implement such policies compared to the permanent changes in tax rates. Moreover, active tax policies can play an important role in stabilizing an economy where monetary policy cannot be used for the stabilization purpose, such as in the member countries of the European Union. 


\section{A Appendix}

\section{A.1 The first-order conditions}

The domestic economy is described by the following 12 equations together with equations for productivity shocks and tax processes:

$$
\begin{aligned}
0 & =(1-\sigma) U_{t}-\left[C_{t}^{\theta}\left(1-L_{t}\right)^{1-\theta}\right]^{1-\sigma} \\
0 & =Y_{t}-A_{t} L_{t}^{\alpha} K_{t}^{1-\alpha} \\
0 & =\lambda_{t} C_{t}\left(1+\tau_{c t}\right)-\theta(1-\sigma) U_{t} \\
0 & =\left(1-\tau_{l t}\right) \lambda_{t} w_{t}\left(1-L_{t}\right)-(1-\theta)(1-\sigma) U_{t} \\
0 & =K_{t+1}-\left[\delta\left(I_{t} / \delta\right)^{1-\phi}+(1-\delta) K_{t}^{1-\phi}\right]^{\frac{1}{1-\phi}} \\
0 & =\beta R_{t} \mathrm{E}_{\mathrm{t}}\left(\lambda_{t+1}\right)-\lambda_{t}\left(1+\zeta B_{t}\right) \\
0 & =G_{t}+T_{t}-\tau_{c t} C_{t}-\tau_{l t} w_{t} L_{t}-\tau_{k t}\left(r_{t}-\delta\right) K_{t}-\frac{\zeta}{2}\left(B_{t}\right)^{2} \\
0 & =Y_{t}+R_{t-1} B_{t-1}-C_{t}-I_{t}-G_{t}-B_{t}, \\
0 & =w_{t} L_{t}-\alpha Y_{t}, \\
0 & =r_{t} K_{t}-(1-\alpha) Y_{t}, \\
0 & =\lambda_{t}-\mu_{t}\left[\delta\left(I_{t} / \delta\right)^{1-\phi}+(1-\delta) K_{t}^{1-\phi}\right]^{\frac{\phi}{1-\phi}}\left(\frac{I_{t}}{\delta}\right)^{-\phi} \\
0 & =\mu_{t}-\beta \mathrm{E}_{\mathrm{t}}\left[\quad(1-\delta) \lambda_{t+1}\left(I_{t+1} / \delta\right)^{\phi}\left(K_{t+1}\right)^{-\phi}\right]
\end{aligned}
$$

where $\lambda_{t}$ and $\mu_{t}$ are Lagrangian multipliers for the budget constraint and capital accumulation equation, respectively. There are foreign country analogues to the above equations. The world equilibrium is achieved by imposing the world resource constraint.

\section{A.2 The bias correction method}

This appendix briefly explains how we calculate the level of welfare using the "bias-correction" method which correctly approximates the solution up to the second-order. For details, see Kim and Kim (2003) and Kim et al. (2003). Most dynamic stochastic models can be cast into the following form:

$$
G\left(w_{t}, w_{t-1}, \varepsilon_{t}\right)+\Pi\left(w_{t}-\mathrm{E}_{\mathrm{t}-1}\left[w_{t}\right]\right)=0,
$$

where $G(\cdot)$ is an $n$-valued function, $w_{t}$ is an $n$-dimensional column vector of variables, $\varepsilon_{t}$ is an $m$-dimensional column vector of independent and identi- 
cally distributed variables, and $\Pi$ is an $(n \times n)$ matrix denoting whether an equation is expectational or not. The i.i.d shocks satisfy

$$
\mathrm{E}\left[\varepsilon_{t}\right]=0, \mathrm{E}\left[\varepsilon_{t} \varepsilon_{t}^{\prime}\right]=\left[\begin{array}{ccc}
\sigma_{1}^{2} & 0 & 0 \\
& \ddots & 0 \\
& & \sigma_{m}^{2}
\end{array}\right]
$$

where each variance is $O\left(\sigma^{2}\right)$. We assume that a solution to (A1) exists and is unique:

$$
w_{t}=F\left(w_{t-1}, \varepsilon_{t}, \sigma\right)
$$

We are interested in deriving the level of welfare

$$
\mathcal{W}=\mathrm{E}\left[U(\bar{w})+U^{\prime}(\bar{w}) w_{\tau}+\frac{1}{2} w_{\tau}^{\prime} U^{\prime \prime}(\bar{w}) w_{\tau}\right] .
$$

The second-order accurate solution of the model would be

$$
w_{t}=F_{1} w_{t-1}+F_{2} \varepsilon_{t}+\frac{1}{2}\left[\begin{array}{c}
\left(I_{n} \otimes w_{t-1}^{\prime}\right) F_{11}\left(\iota_{n} \otimes w_{t-1}\right) \\
+2\left(I_{n} \otimes w_{t-1}^{\prime}\right) F_{12}\left(\iota_{n} \otimes \varepsilon_{t}\right) \\
+\left(I_{n} \otimes \varepsilon_{t}^{\prime}\right) F_{22}\left(\iota_{n} \otimes \varepsilon_{t}\right)
\end{array}\right]+\frac{\sigma^{2}}{2} F_{33},
$$

where $\otimes$ is the Kronecker product and $\iota_{n}$ is an $n$-tuple of ones. Now a second-order accurate representation of the level of welfare is

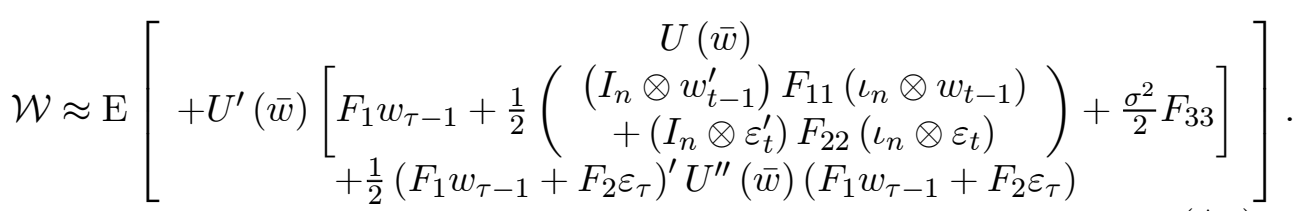

However, if we used a solution based on the linear approximation of the model (i.e. $w_{t}=F_{1} w_{t-1}+F_{2} \varepsilon_{t}$, the first two terms in (A4)), instead of the quadratic solution, then our evaluation of welfare would miss the terms involving $F_{11}, F_{22}$ and $F_{33}$. However, these terms are as important as the first-order terms in computing the level of welfare and omitting them would produce inaccuracies in analyzing welfare implications.

Having shown that the inclusion of $F_{11}, F_{22}$ and $F_{33}$ are critical in welfare analysis, we also note that computing them (and $F_{12}$ ) is a burdensome task (e.g. Kim et al. 2003). To avoid this computational burden, Kim and Kim (2003) proposed a method based on the idea of bias correction in econometrics. The method starts by positing a linear solution as follows:

$$
w_{t}=\eta_{t}+F_{1} w_{t-1}+F_{2} \varepsilon_{t},
$$


where $\eta_{t}$ is the bias correction term. This term is time-varying, but does not depend on the variables of the model. The method then pins down the $n$-dimensional $\eta_{t}$ term by solving the following $n$ equations:

$$
\begin{aligned}
0 & =\mathrm{E}\left[G\left(w_{t}, w_{t-1}, \varepsilon_{t}\right)+\Pi\left(w_{t}-\mathrm{E}_{\mathrm{t}-1}\left[w_{t}\right]\right)\right] \\
& =\mathrm{E}\left[G\left(\eta_{t}+F_{1} w_{t-1}+F_{2} \varepsilon_{t}, w_{t-1}, \varepsilon_{t}\right)\right]
\end{aligned}
$$

which shows that the model equations hold on average, even though not state by state. This assumption is, however, less restrictive than positing linear approximation of the model equations. This equation also shows intuitively why this method yields more terms than the linear method. An advantage of this bias correction method is that we don't need to solve for $F_{11}, F_{22}$ or $F_{33}$. It just takes the second derivatives of $G(\cdot)$ as inputs and computes the $\eta_{t}$ term as an output. Kim and Kim (2003) proves that this bias correction method produces the same level of welfare as the second order approximation method. This proof is based on an observation that the solution of the above system of equations satisfies

$$
\eta_{t}=\mathrm{E}\left[\frac{1}{2}\left[\left(I_{n} \otimes w_{t-1}^{\prime}\right) F_{11}\left(\iota_{n} \otimes w_{t-1}\right)+\left(I_{n} \otimes \varepsilon_{t}^{\prime}\right) F_{22}\left(\iota_{n} \otimes \varepsilon_{t}\right)\right]+\frac{\sigma^{2}}{2} F_{33}\right] .
$$




\section{References}

[1] Backus, D., P. Kehoe, and F. Kydland, 1992, International Real Business Cycles, Journal of Political Economy 100, 745-775.

[2] Baxter, M., 1997, International Trade and Business Cycles, in: G.H. Grossman and K. Rogoff, eds., Handbook of International Economics, Vol. 3 (North-Holland, Amsterdam).

[3] Baxter, M. and M. Crucini, 1995, Business Cycles and the Asset Structure of Foreign Trade, International Economic Review 36, 821-854.

[4] Bovenberg, L., 1994, Capital Taxation in the World Economy, in: F. Van der Ploeg, ed., Handbook of International Macroeconomics (Blackwell, Cambridge).

[5] Canzoneri, M., R. Cumby, and B. Diba, 2002, The Need for International Policy Coordination: What's Old, What's New, What's Yet to Come?, mimeo.

[6] Chari, V., L. Christiano, and P. Kehoe, 1994, Optimal Fiscal Policy in a Business Cycle Model, Journal of Political Economy 102, 617-652.

[7] Easley, D., N. Kiefer, and U. Possen, 1993, An Equilibrium Analysis of Fiscal Policy with Uncertainty and Incomplete Markets, International Economic Review 34, 935-952.

[8] Easterly, W. and S. Rebelo, 1993, Fiscal Policy and Economic Growth: An Empirical Investigation, Journal of Monetary Economics 32, 417458.

[9] Feldstein, M., 2002, The Role for Discretionary Fiscal Policy in a Low Interest Rate Environment, NBER Working Paper No.9203.

[10] Frenkel, J. and A. Razin, 1992, Fiscal Policies and the World Economy (MIT Press, Cambridge).

[11] Gorostiaga, A., 2003, Should Fiscal Policy Be Different in a NonCompetitive Framework?, Journal of Monetary Economics 50, 13111331.

[12] Greenwood, J. and G. Huffman, 1991, Tax Analysis in a Real-BusinessCycle Model: On Measuring Harberger Triangles and Okun Gaps, Journal of Monetary Economics 27, 167-190. 
[13] Hairault, J, Langot, F, and Portier, F., 2001, Efficiency and Stabilization: Reducing Harberger Triangles and Okun Gaps, Economics Letters, 70, 209-214.

[14] Heathcote, J. and F. Perri, 2002, Financial Autarky and International Business Cycles, Journal of Monetary Economics 49, 601-627.

[15] Ireland, P., 1996, The Role of Countercyclical Monetary Policy, Journal of Political Economy, 104, 704-723.

[16] Karayalcin, C., 1995, Capital Income Taxation and Welfare in a Small Open Economy, Journal of International Money and Finance 14, 785800 .

[17] Kim, J., 2003, Functional Equivalence Between Intertemporal and Multisectoral Investment Adjustment Costs, Journal of Economic Dynamics and Control, 27 (4), 533-549.

[18] Kim, J. and D. Henderson, 2002, Inflation Targeting and Nominal Income Growth Targeting: When and Why Are They Suboptimal?, International Finance Discussion Papers \#719, Federal Reserve Board.

[19] Kim, J. and S.H. Kim, 2003, Spurious Welfare Reversals in International Business Cycle Models, Journal of International Economics 60, 471-500.

[20] Kim, J., S.H. Kim, and A. Levin, forthcoming, Patience, Persistence, and Welfare Costs of Incomplete Markets in Open Economies, Journal of International Economics.

[21] Kim, J., S.H. Kim, E. Schaumburg, and C. Sims, 2003, Calculating and Using Second Order Accurate Solution of Discrete Time Dynamic Equilibrium Models, mimeo.

[22] Kim, S.H., and A. Kose. 2003, Dynamics of Open Economy Business Cycle Models: Understanding the Role of the Discount Factor, Macroeconomic Dynamics 7, 263-90.

[23] King, R., C. Plosser, and S. Rebelo, 1988, Production, Growth and Business Cycles: I. The Basic Neoclassical Mode, Journal of Monetary Economics 21, 195-232.

[24] Kollmann, R., 1998, US Trade Balance Dynamics: The Role of Fiscal Policy and Productivity Shocks and of Financial Market Linkage, Journal of International Money and Finance 17, 637-669. 
[25] Lucas, R. Jr., 1987, Models of Business Cycles, Cambridge, MA: Blackwell.

[26] Lucas, R. Jr., 1990, Supply-Side Economics: An Analytical Review, Oxford Economic Papers 42, 293-316.

[27] McGrattan, E., 1994, The Macroeconomic Effects of Distortionary Taxation, Journal of Monetary Economics 33, 573-601.

[28] Mendoza, E., A. Razin, and L. Tesar, 1994, Effective Tax Rates in Macroeconomics: Cross-Country Estimates of Tax Rates on Factor Incomes and Consumption, Journal of Monetary Economics 34, 297-323.

[29] Mendoza, E. and L. Tesar, 1998, The International Ramifications of Tax Reforms: Supply-Side Economics in a Global Economy, American Economic Review 88, 226-245.

[30] Mendoza, E. and L. Tesar, 2001, Tax Competition vs. Tax Coordination Under Perfect Capital Mobility: The Supply-Side Economics of International Tax Competition, mimeo.

[31] Obstfeld, M. and K. Rogoff, 2002, Global Implications of Self-Oriented National Monetary Rules, Quarterly Journal of Economics, 503-535.

[32] Razin, A. and E. Sadka, 1994, International Fiscal Policy Coordination and Competition, in: F. Van der Ploeg, ed., The Handbook of International Macroeconomics (Blackwell, Cambridge).

[33] Schmitt-Grohé, S. and M. Uribe, 2003, Closing small open economy models, Journal of International Economics 61, 163-185.

[34] Yakadina, I., 2002, Optimal Capital-Labor Taxes under Uncertainty and Limits on Debt, mimeo. 


\section{Table 1. Properties of estimated tax rates}

$<$ Average tax rates $>$

\begin{tabular}{|l|c|c|c|}
\hline & C-tax & L-tax & K- tax \\
\hline Canada & 0.12 & 0.25 & 0.43 \\
France & 0.20 & 0.42 & 0.24 \\
Germany & 0.16 & 0.38 & 0.27 \\
Italy & 0.13 & 0.41 & 0.29 \\
Japan & 0.05 & 0.22 & 0.35 \\
UK & 0.15 & 0.25 & 0.55 \\
US & 0.06 & 0.26 & 0.42 \\
\hline average & 0.12 & 0.31 & 0.36 \\
\hline
\end{tabular}

$<$ Correlation among different tax rates $>$

\begin{tabular}{|l|l|l|l|l|}
\hline & $\begin{array}{l}\text { C-tax } \\
\text { L-tax }\end{array}$ & $\begin{array}{l}\text { C-tax } \\
\text { K-tax }\end{array}$ & $\begin{array}{l}\text { L-tax } \\
\text { K-tax }\end{array}$ & average \\
\hline Canada & -0.45 & -0.34 & 0.60 & -0.06 \\
France & -0.72 & 0.25 & 0.02 & -0.15 \\
Germany & -0.05 & 0.36 & 0.63 & 0.07 \\
Italy & 0.88 & 0.84 & 0.90 & 0.87 \\
Japan & 0.10 & -0.11 & 0.95 & 0.31 \\
UK & 0.17 & 0.10 & 0.64 & 0.32 \\
US & -0.76 & 0.40 & -0.10 & -0.15 \\
\hline average & -0.12 & 0.11 & 0.53 & 0.17 \\
\hline
\end{tabular}

Note: C-tax: consumption tax rate, L-tax: labor income tax rate, K-tax: Capital income tax rate. 
Table 2. Estimation of $\mathrm{AR}(1)$ tax rate process

$<$ Persistence $>$

\begin{tabular}{|l|c|c|c|}
\hline & C-tax & L-tax & K-tax \\
\hline Canada & 0.76 & 0.92 & 0.87 \\
France & 0.96 & 0.98 & 0.86 \\
Germany & 0.62 & 0.89 & 0.85 \\
Italy & 0.90 & 0.95 & 0.79 \\
Japan & 0.92 & 0.97 & 0.94 \\
UK & 0.88 & 0.77 & 0.73 \\
US & 0.81 & 0.89 & 0.63 \\
\hline average & 0.84 & 0.91 & 0.81 \\
\hline
\end{tabular}

$<$ Standard deviation of tax shocks $>$

\begin{tabular}{|l|c|c|c|}
\hline & C-tax & L-tax & K-tax \\
\hline Canada & 0.008 & 0.009 & 0.025 \\
France & 0.011 & 0.007 & 0.014 \\
Germany & 0.009 & 0.014 & 0.017 \\
Italy & 0.008 & 0.013 & 0.022 \\
Japan & 0.002 & 0.007 & 0.022 \\
UK & 0.009 & 0.010 & 0.060 \\
US & 0.002 & 0.007 & 0.045 \\
\hline average & 0.007 & 0.010 & 0.027 \\
\hline
\end{tabular}

Note: Tax rates are assumed to follow an $\mathrm{AR}(1)$ process:

$$
\tau_{t}=\rho \tau_{t-1}+(1-\rho) \bar{\tau}+\varepsilon_{\tau_{t}}
$$

where $\varepsilon_{\tau_{t}}$ is defined as tax shock (or tax innovation). Persistence of tax rate is defined as $\rho$. 


\section{Table 3. Welfare effects of tax policies}

\begin{tabular}{|c|c|c|}
\hline & $\left(\eta, \eta^{*}\right)$ & Welfare gains (home, foreign, world) \\
\hline \multirow{3}{*}{ K-tax } & $(-2.2,0)^{1}$ & $(0.0030,0.0014,0.0022)$ \\
& $(-2.8,-2.8)^{2}$ & 0.0065 \\
& $(-5.6,-5.6)^{3}$ & 0.0087 \\
\hline \multirow{3}{*}{ L-tax } & $(-0.2,0)^{1}$ & $(0.0008,0.0006,0.0007)$ \\
& $(-0.2,-0.2)^{2}$ & 0.0015 \\
& $(-0.4,-0.4)^{3}$ & 0.0020 \\
\hline
\end{tabular}

1. Domestic tax policy only

2. Non-cooperative Nash equilibrium

3. Cooperative equilibrium

For 2 and 3, home, foreign and world welfare gains are identical due to the symmetry of countries.

Note: The numbers are percentage welfare gains over the benchmark economy where productivity is subject to shocks but no tax policy shocks are present. Welfare gains are estimated as percentage changes in certainty equivalent consumption level, while the certainty equivalent consumption is calculated from conditional welfare changes over the benchmark economy. 


\section{Table 4. Sensitivity Analysis}

$<$ With both income tax policies $>$

\begin{tabular}{|c|c|}
\hline$\left(\begin{array}{cc}\eta_{k} & \eta_{k}^{*} \\
\eta_{l} & \eta_{l}^{*}\end{array}\right)$ & Welfare gains (home, foreign, world) \\
\hline$\left(\begin{array}{rr}-2.8 & 0 \\
-0.4 & 0\end{array}\right)$ & $(0.0048,0.0054,0.0051)$ \\
\hline$\left(\begin{array}{rr}-3.3 & -3.3 \\
-0.4 & -0.4\end{array}\right)^{2}$ & $(0.0125)$ \\
\hline$\left(\begin{array}{cc}-16.0 & -16.0 \\
-2.3 & -2.3\end{array}\right)^{3}$ & $(0.0347)$ \\
\hline
\end{tabular}

$<$ With varying consumption tax rate $>$

\begin{tabular}{|c|c|c|}
\hline & $\left(\eta, \eta^{*}\right)$ & Welfare gains (home, foreign, world) \\
\hline K-tax & $(-1.7,0)^{1}$ & $(0.0066,0.0017,0.0042)$ \\
\hline L-tax & $(0.6,0)^{1}$ & $(0.0029,0.0006,0.0017)$ \\
\hline
\end{tabular}

1. Domestic tax policy only

2. Non-cooperative Nash equilibrium

3. Cooperative equilibrium

For 2 and 3, home, foreign and world welfare gains are identical due to the symmetry of countries. 


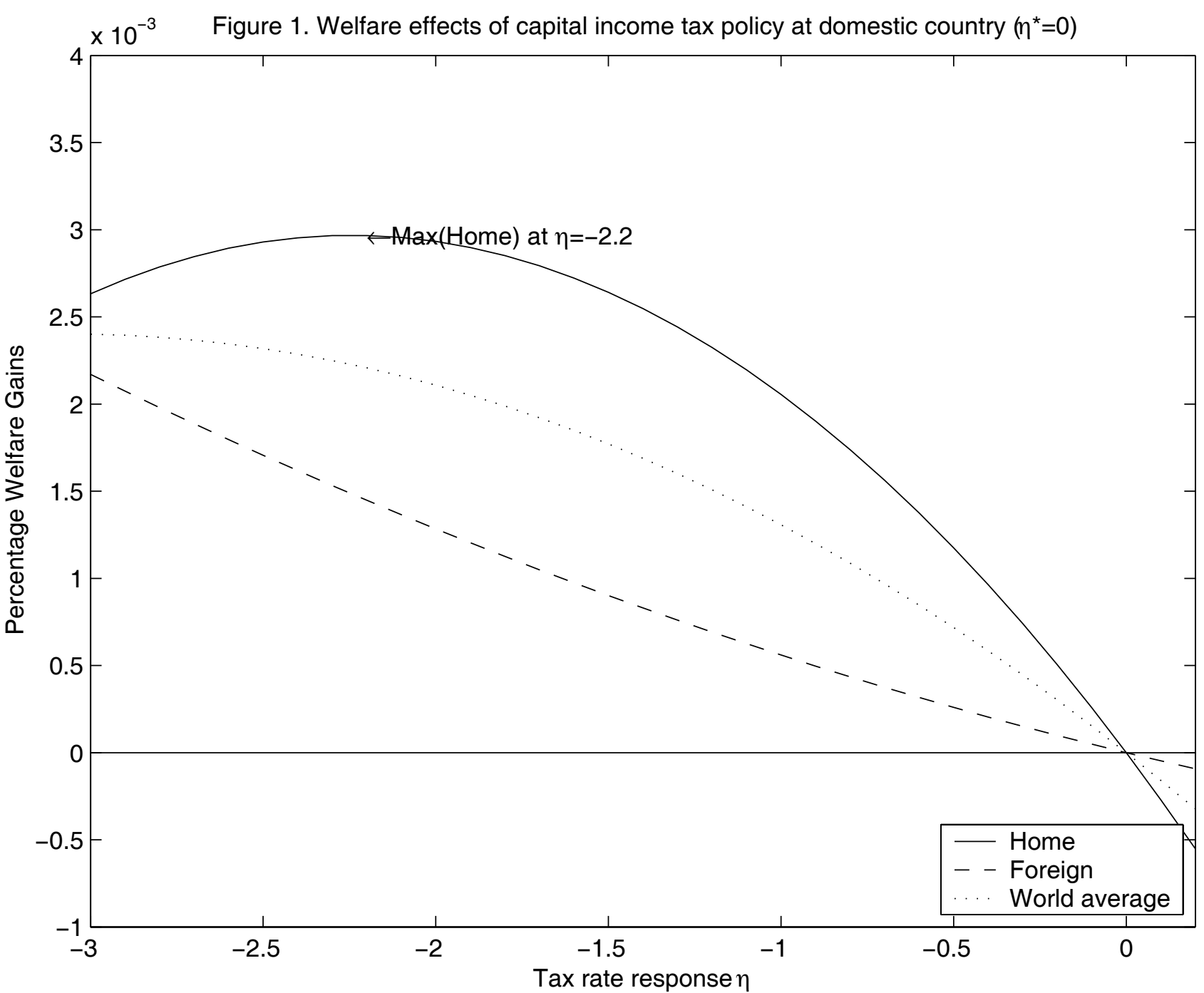


Figure 2. Impulse responses to $1 \%$ increase in productivity at Home: capital income tax $(\eta=-2.2)$
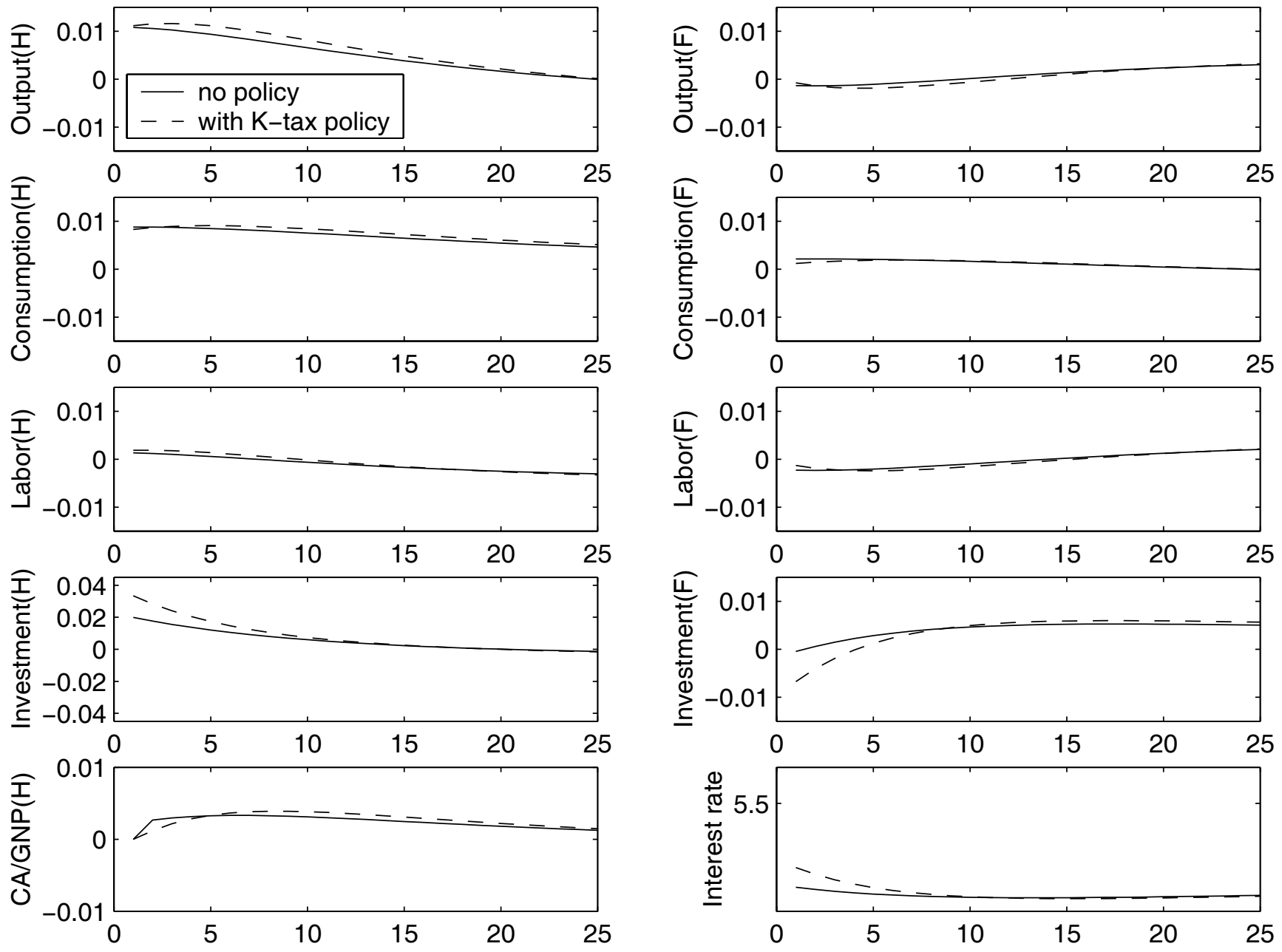
Figure 3. Tax policy reaction functions (capital income tax)

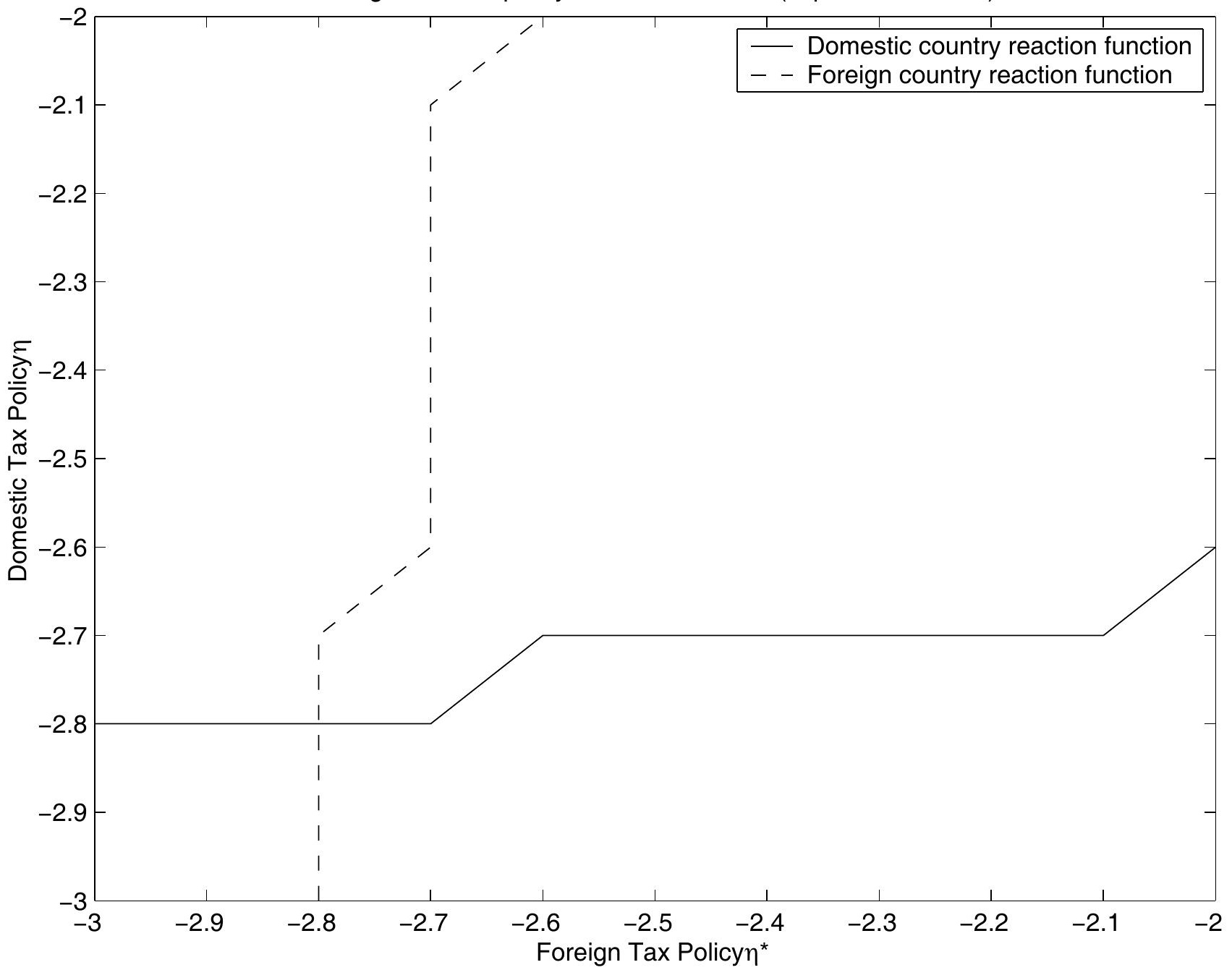


Figure 5 . Impulse responses to $1 \%$ increase in productivity at Home: labor income tax $(\eta=-0.2)$
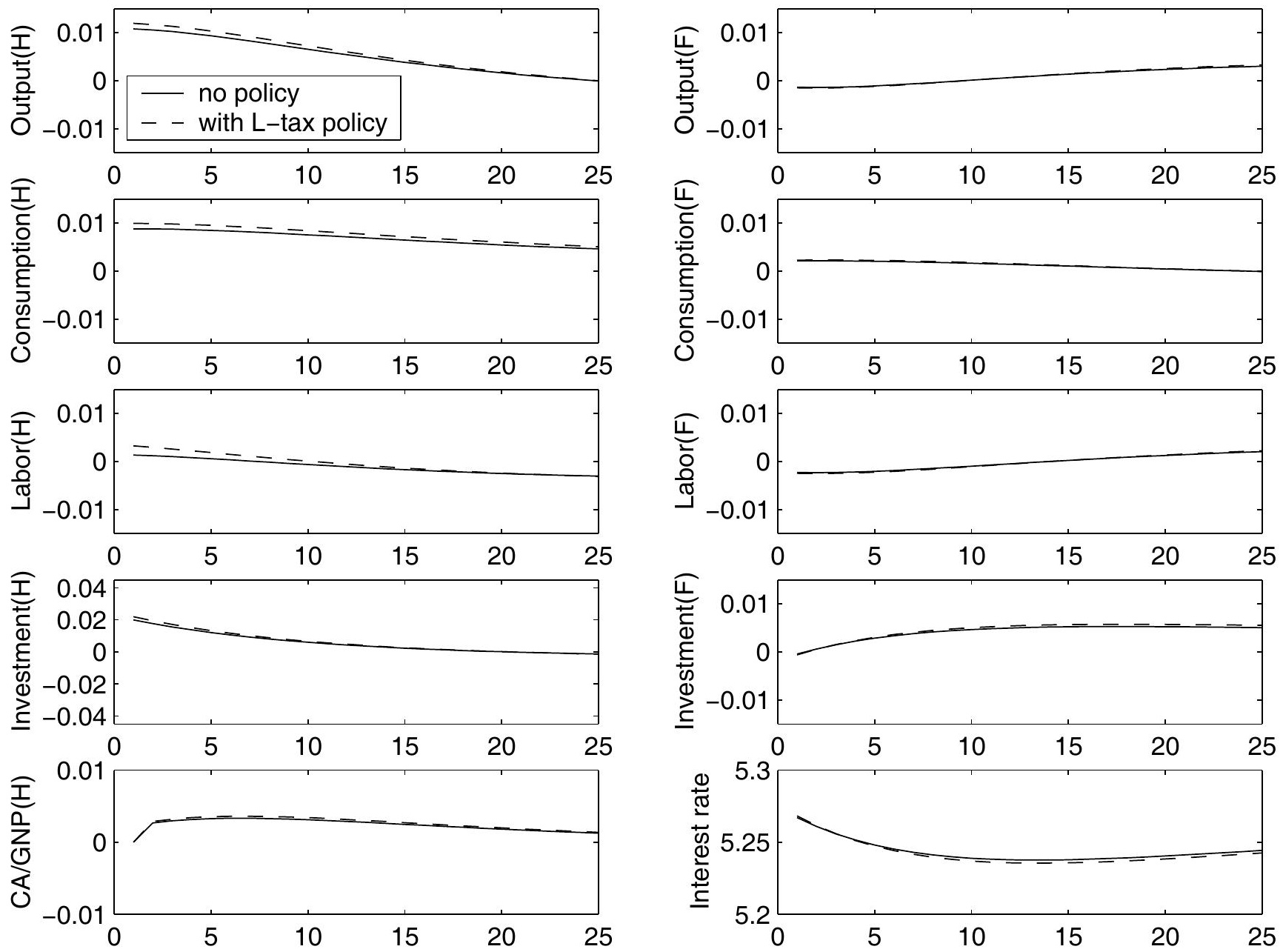
Figure 6. Tax policy reaction functions (labor income tax)

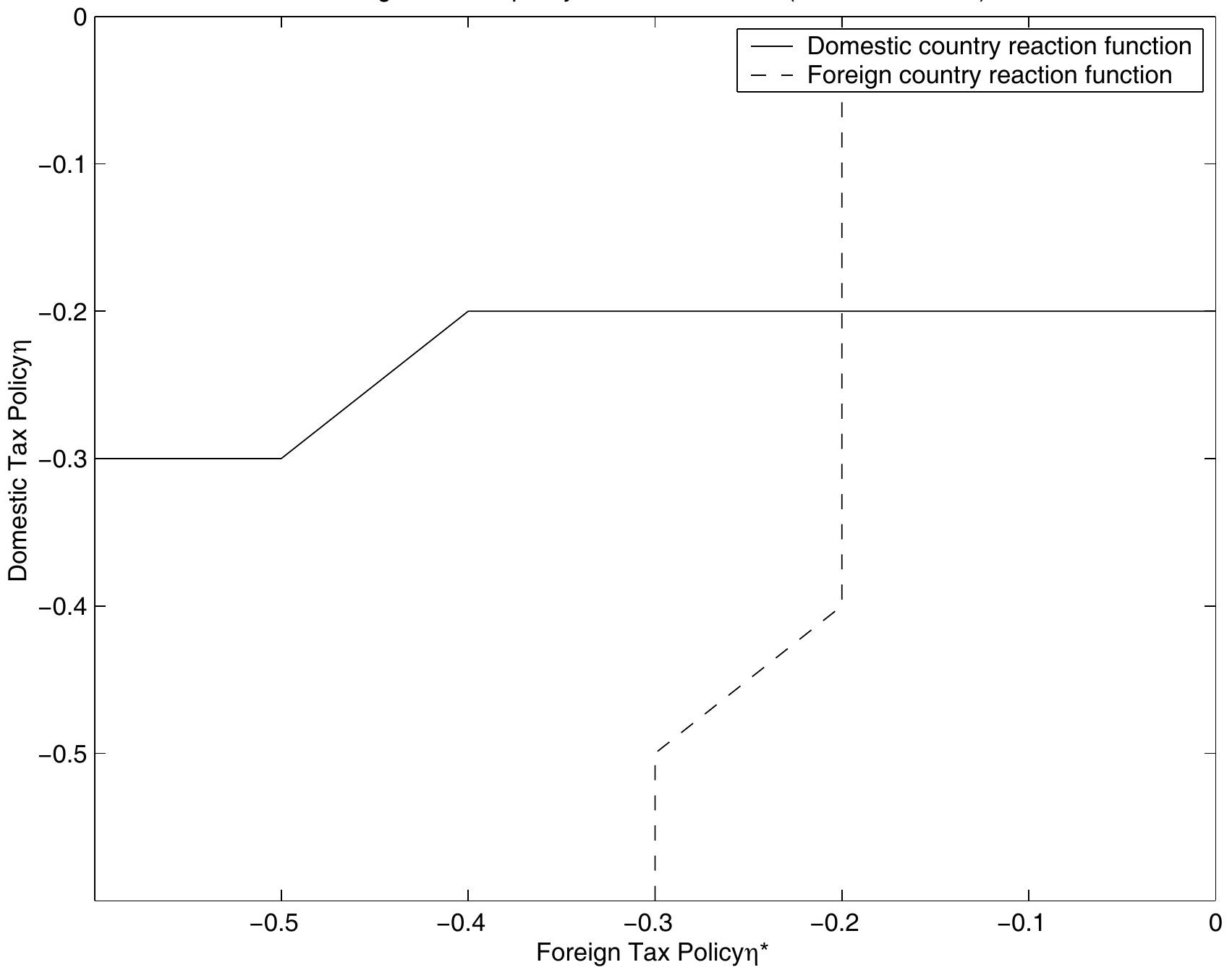


Figure 7 . Impulse responses to $1 \%$ increase in productivity at Home: no tax policy
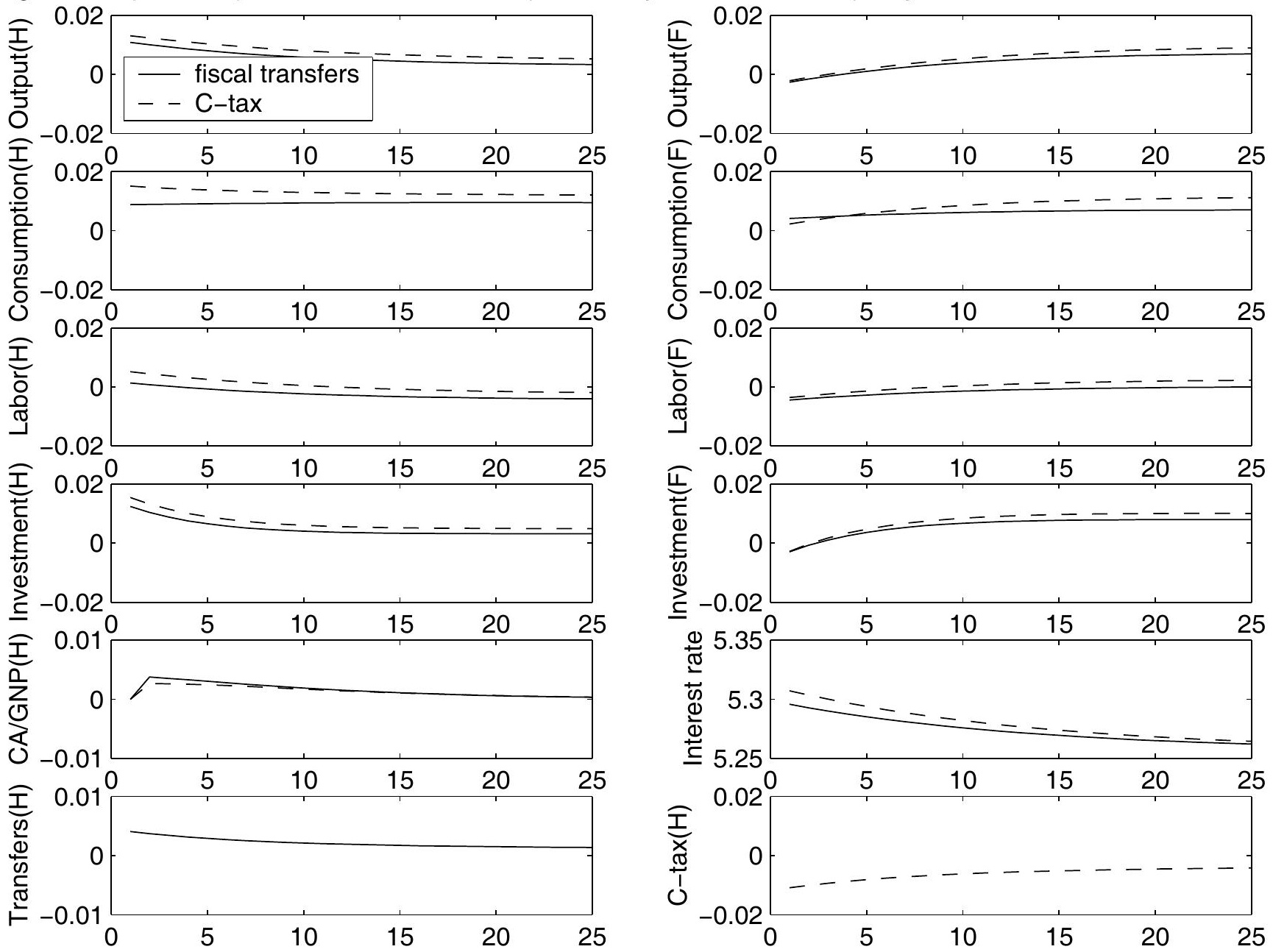